\title{
Konsep dasar sejarah: Pengantar untuk pembelajaran IPS
}

\section{Miftakhuddin, Anwar Senen}

Universitas Negeri Yogyakarta, Indonesia

\author{
A R T I C L E I N F O \\ Article history: \\ Received 01 Januari 2021 \\ Accepted 12 April 2021 \\ Available online 30 Juni \\ 2021 \\ Kata Kunci: \\ Konsep dasar sejarah \\ Pembelajaran IPS \\ Pendidikan sejarah \\ Pembelajaran sejarah \\ Keywords: \\ Basic concept of history \\ Social studies learning \\ History education \\ History learning
}

\begin{abstract}
A B S T R A K
Sejarah merupakan bagian dari ilmu sosial yang sebetulnya bisa dipahami dengan mudah jika mengikuti bagaimana cara berpikir sejarawan dan bagaimana cara kerja metodologi sejarah. Tidak seperti profesi dokter yang harus diisi oleh orang dari disiplin ilmu kedokteran. Siapapun bisa menjadi sejarawan, karena sejarah merupakan ilmu yang terbuka. Setiap orang punya kesempatan yang sama untuk menjadi sejarawan selaman dia bisa menjalankan metodologi sejarah dengan konsisten dan baik. Demikian juga dengan pemahaman sejarah. Sejarah harus dipahami dari berbagai sudut pandang sebagaimana berbagai ruang lingkup yang dimiliki oleh sejarah. Bagi orang-orang keguruan atau kependidikan, pemahaman tentang kedudukan sejarah dalam ilmu sosial dan kedudukan sejarah dalam IPS, akan sangat membantu dalam menyampaikan materi sejarah di ruang-ruang kelas. Terlebih lagi jika mereka dapat mengamalkan kaidah penyampaian sejarah sesuai dengan jenjang pendidikan siswa di satuan pendidikan.
\end{abstract}

A B S T R A C T

History is a part of social science which can actually be understood easily if you follow how historians think and how historical methodologies work. Unlike the medical profession which must be filled by people from medical disciplines. Anyone can become a historian, because history is an open science. Everyone has the same opportunity to become a historian as long as he can carry out the historical methodology consistently and well. Likewise with historical understanding. History must be understood from various points of view as well as the various scopes that history has. For teachers or educators, an understanding of the position of history in social sciences and the position of history in social studies, will be very helpful in conveying historical material in classrooms. Moreover, if they can practice the rules of delivering history according to the level of education of students in the education unit.

Copyright (C) osf.io. All rights reserved.

\section{Pendahuluan}

Sejarah termasuk ilmu sosial yang tidak gampang dipahami begitu saja. Kurang lebih, demikianlah anggapan banyak kalangan soal ilmu sejarah. Bahkan, dalam pemahamannya, sering terjadi tumpang tindih antara pemahaman sejarah dengan pemahaman arkeologi, filologi, dan antropologi. Padahal, masing-masing ilmu tersebut mempunyai metode dan objek kajian yang sama sekali berbeda, walaupun secara empiris pemerolehan fakta terkadang menggunakan subjek yang sama. Lebih rumit lagi, sejarah mendapatkan tempat dalam kurikulum sekolah, yangmana ini berarti sejarah harus dipahami tidak hanya secara metodologis, melainkan juga harus dimengerti secara pedagogis (Miftakhuddin, et. al., 2019). Demikian juga pemahaman terhadap kedudukan sejarah dalam ilmu sosial (social science), dan kedudukan sejarah dalam IPS (social studies). Hal ini penting, karena menurut Senen (2014), ilmu sosial dipolakan untuk mengembangkan human knowledge melalui riset, sedangkan IPS lebih ke tujuan instruksional dengan mengintegrasikan semua disiplin ilmu sosial, tapi disajikan dengan sesederhana 
mungkin. Inilah alasan mengapa ada banyak sekali kriteria dan strategi yang harus ditempuh guru dalam menyelenggarakan pembelajaran IPS di sekolah. Banyak kasus bahkan menunjukkan bahwa guru bukan hanya berfokus kepada metode pembelajaran dan pengusaan bahan ajar, melainkan juga harus berfokus kepada media dan sumber belajar otentik (Khoiron, et. al., 2020).

Oleh karena itu, perlu pengkajian mendalam -utamanya bagi mahasiswa- agar mendapat pemahaman yang utuh tentang sudut pandang sejarah secara umum dan batasan-batasan yang jelas antara ilmu sejarah dengan ilmu sosial lainnya. Selebihnya, juga agar mahasiswa memperoleh pemahaman soal perbedaan sejarah dalam social science, dengan sejarah dalam social studies. Guna mencapai tujuan-tujuan itu, pembahasan harus bertumpu kepada para pakar sejarah dari Indonesia seperti Sartono Kartodirdjo dan Kuntowijowo, serta sejarawan luar Indonesia yang kerap mengkaji sejarah Indonesia, seperti Peter Carey dan M. C. Ricklefs.

\section{Rumusan masalah}

Rumusan masalah dalam paper ini ialah: (1) Ranah mana saja yang merupakan lingkup kajian sejarah?, (2) Apa nilai moral yang terkandung dalam sejarah?, dan (3) Apa saja tujuan dan manfaat mempelajari sejarah?.

\section{Hasil dan pembahasan}

Definisi yang diberikan kepada sejarah sudah tidak bisa dihitung lagi banyaknya. Bahkan tidak ada diantara mereka yang melakukan klasifikasi terhadap pengertian-pengertian tersebut. Tapi agaknya pengelompokkan itu sangat tidak perlu untuk dilakukan, karena sejarah atau hari lampau itu sangat mudah mengundang tanggapan-tanggapan filosofis, bahkan skeptis dan sarkatis (Abdullah, 1978). Jika mau, ambil contoh pengertian sejarah secara etimologis yang banyak muncul di artikel bebas dan artikel ilmiah peneliti terdahulu, bahwa term sejarah berasal dari bahasa Arab syajaratun (syajaroh) yang berarti pohon, dimana term ini juga merujuk pada konsep keturunan dan silsilah. Tapi dalam praktiknya, pengertian sejarah justeru selalu merujuk pada term "historia" (bahasa Yunani, dibaca: istoria), yang artinya mengetahui ilmu dengan menyelidiki, dimana term ini kemudian diasosikan sebagai pertelaahan mengenai hal ihwal manusia dalam urutan kronologisnya (Brahmantyo, 2018; Ismaun, 2016; Sjamsuddin, 1996).

Akan tetapi, menurut Abdullah (1978), pada pengertian pertama sejarah adalah sesuatu yang terjadi; "ia terjadi". Baik dikatakan atau tidak, diceritakan atau tidak, dan dicatat atau tidak, sesuatu yang telah terjadi adalah sejarah. Sedangkan pada pengertian kedua ialah upaya menceritakan dan menerangkan kembali apa yang sudah terjadi itu. Pengertian kedua di atas memposisikan sejarah sebagai bidang ilmu yang mengambil seluruh kegiatan dan aktivitas manusia dan dampak yang ditimbulkannya sebagai domain kajiannya; mulai dari perang yang dapat menghadirkan kehancuran, hingga agama yang menjanjikan kebahagiaan. Sesuai pengertian kedua itu, dalam konteks penelitian akademis, Kuntowijoyo (2013) menganggap sejarah sebagai rekonstruksi masa lalu.

\section{Konsep dasar sejarah}

Beragamnya pengertian sejarah pada akhirnya bermuara pada sebuah kesepakatan, bahwa sekurang-kurangnya ada tiga komponen dalam pengertian sejarah secara konseptual. Ketiganya meliputi; sejarah sebagai peristiwa, sejarah sebagai kisah/cerita, dan sejarah sebagai ilmu (Ismaun, 2016). Karena merupakan suatu pengertian konseptual, ketiganya dapat diasumsikan sebagai rumusan, sebagai peranan dan kedudukan, bahkan sebagai sudut pandang atau perspektif. Terlepas dari perbedaan anggapan tersebut, berangkat dari tiga konsep dasar itulah baru kemudian sejarah akan terbagi secara tematis ke dalam beberapa ruang lingkup, seperti: sejarah sosial, sejarah ekonomi, sejarah kebudayaan, sejarah demografi, sejarah politik, sejarah intelektual, sejarah keluarga, sejarah etnis, dan sejarah yang spesifik lainnya. Sementara, sebelum pembahasan masuk pada ruang lingkup, terlebih dahulu perlu dipahami tiga rumusan (konsep dasar) sejarah di bawah ini. 


\section{Sejarah sebagai peristiwa}

Jika kita berpegang teguh pada dua konsep sejarah yang diungkapkan Abdullah (1978), kita akan sampai pada kesimpulan bahwa apa yang sebetulnya menjadi sejarah -dalam pengertian ilmiah- ialah hanya terbatas pada kejadian yang mempunyai makna sosial (berhubungan dengan manusia); peristiwa. Tentu saja, serangkaian peristiwa itu harus didukung oleh evidensi yang dapat membuktikan peristiwa tersebut benar adanya, terutama evidensi berupa sumber-sumber primer. Bila kriteria ini terpenuhi, maka sejarah dapat memenuhi syarat objektivitasnya sebagai bidang ilmu yang merekam masa lampau secara valid. Salah satu contohnya adalah sejarah tentang kolonialisme, yang dalam karya Miftakhuddin (2020) disebut-sebut bukan hanya mengakibatkan de-civilization, melainkan juga re-civilization. Segala peristiwa dalam tulisan Miftakhuddin (2020) didukung oleh banyak dokumen-dokumen valid yang membuktikan bahwa peristiwa kolonialisme memang bukan banya perombakan stuktur sosial budaya yang sudah mapan, melainkan kolonialisme juga diiringi oleh pembangunan berkelanjutan dan sentralisasi kekuasaan (hegemoni).

Hal inipun rupanya juga diperkuat oleh Sunal \& Haas (2011). Menurutnya, sejarah adalah kajian kronologis yang menafsirkan dan memberi makna terhadap peristiwa dengan menerapkan metode yang sistematis untuk mengungkapkan fakta. Suatu kejadian yang biasa terjadi tidak akan menjadi kajian sejarah; akan tetap menjadi sebuah kejadian. Namun jika sesuatu yang lazim terjadi itu mempunyai makna sosial, maka itu akan diambil oleh sejarah sebagai suatu topik yang bagus untuk dikaji (Brahmantyo, 2018). Demikianlah suatu kejadian di waktu tertentu akan menjadi peristiwa jika ia mempunyai makna. Abdullah (1978) membahasakan konsep ini dengan lebih spesifik. Menurutnya, suatu kejadian menjadi peristiwa dalam pengertian sejarah, ia tidak melekat pada dirinya, melainkan pada nilai yang dikenakan pada dirinya. Bukan hanya itu, suatu kejadian bisa diklaim sebagai persitiwa historis jika ia dianggap relevan dengan masalah yang dihadapi.

Di Indonesia, contoh peristiwa sejarah yang banyak dikenal ialah proklamasi kemerdekaan Indonesia tanggal 17 Agustus 1945, atau menyerahnya Jepang kepada Sekutu pada tanggal 14 Agustus 1945. Itu adalah contoh sejarah sebagai perisiwa. Sejarah sebagai peristiwa juga mempunyai arti peristiwa dalam sejarah tidak akan berulang, karena terikat oleh waktu yang telah lampau. Terkait pengulangan sejarah ini, Santoso (2014) menegaskan sejarah dapat dipandang dari arti subjektif dan arti objektif. Sejarah dalam arti subjektif menunjuk pada cerita sejarah yang dituturkan oleh penulis dalam bentuk historiografi maupun rekonstruksi lisan. Sedangkan dalam arti objektif menunjuk pada peristiwa itu sendiri. Keseluruhan proses/peristiwa itu berlangsung terlepas dari subjek manapun; objektif berarti tidak memuat unsur subjek, yaitu pembuat cerita/sejarawan (Kartodirdjo, 1992). Sejarah akan objektif jika mereka didokumentasikan dengan rajin dan bijak. Filosofi sejarahnya ialah memurnikan peristiwa; hanya mengatakan apa yang sebetulnya memang terjadi (Arnold, 2000).

Meski begitu, harus dipahami tidak semua peristiwa penting di masa lalu merupakan sejarah, karena sebagian dari masa lalu juga merupakan pra-sejarah, yang menjadi fokus arkeologi (Santoso, 2014). Menurut Kuntowijoyo (1995), ada kesepakatan tidak tertulis antara pembabakan waktu untuk arkeologi dan untuk sejarah di Indonesia yang hingga kini masih berlaku, yaitu sejarah akan mengkaji peristiwa yang terjadi sesudah tahun 1500. Sejarah hanya mengurusi manusia masa kini, meski manusia masa kini juga merupakan objek bersama-sama dengan sosiologi, politik, dan antropologi. Terlebih lagi, masa pra-sejarah adalah masa dimana manusia belum mengenal tulisan. Sehingga tidak ada bukti dokumen untuk membawa peristiwa itu ke dalam ranah sejarah. Semakin peristiwa itu jauh di belakang kehidupan kita, maka akan semakin sulit untuk menemukan sumber primer dan dokumen yang merekam peristiwa tersebut. Begitu pula sebaliknya (Santoso, 2014).

\section{Sejarah sebagai kisah/cerita}

Herodotus (484-425 SM), yang digelari sebagai Bapak Sejarah, adalah orang yang memulai sejarah sebagai cerita; story telling (Sjamsuddin, 1996). Sejarah sebagai kisah ialah cerita berupa narasi yang disusun dari memori, kesan atau tafsiran manusia terhadap peristiwa yang terjadi pada masa lampau. Maka dari itu sejarah sebagai kisah ini lebih banyak mengandung subjektivitas. Awalnya orang akan berusaha mengisahkan sejarah dengan objektif, 
tapi saat ia melakukannya, mau tidak mau ia akan dipengaruhi sifat manusiawinya dan menjadi subjektif (Ismaun, 2016). Contohnya ialah sejarah Diponegoro, jika dikisahkan oleh kolonial Belanda, barangkali akan dikisahkan sebagai pemberontak. Namun jika dikisahkan oleh pujangga kerajaan Jawa, Diponegoro dikisahkan sebagai pahlawan. Hanya peneliti sejarah yang tidak berkepentingan yang bisa mengisahkan Diponegoro secara berimbang (proporsional), seperti Peter Carey misalnya, yang telah mempublikasikan banyak buku hasil riset tentang Pangeran Diponegoro dan perjalanan hidupnya. Namun historiografi dari sejarawan itupun juga boleh untuk dikritik atau diulas, asalkan dilakukan secara berimbang dan menggunakan metodologi yang memadai. Contohnya adalah review yang dilakukan Miftakhuddin (2020) atas buku tentang sejarah korupsi di Indonesia, karya Peter Carey dan kawan-kawan.

Bedanya dengan sejarah lisan, ialah sejarah lisan mempunyai objektivitas lebih tinggi, karena dituturkan secara langsung tanpa ada jeda untuk merekayasa. Sedangkan perbedaannya dengan mitos ialah sejarah merupakan cerita yang bisa dipertanggungjawabkan (ilmiah) dan mempunyai bukti otentik. Problemnya baru akan mencul manakala cerita sejarah dikombinasi dengan mitologi yang sulit untuk dipilah dan membedakan antara manakah kisah yang merupakan cerita sejarah dan manakah kisah yang merupakan cerita mitos. Problem ini banyak ditemukan dalam kajian tentang relief di candi-candi yang dipahat untuk menceritakan pengalaman suatu kerajaan masa lampau, yang mana terkadang pujangga mengisahkan raja sebagai keturunan dewa (Murwonugroho \& Miftakhuddin, 2020).

Ketika menyampaikan sejarah sebagai kisah, sedikitnya ada dua cara yang bisa ditempuh, yakni sejarah dikisahkan secara interpretatif dan sejarah dikisahkan secara narantif (rinci). Pembahasan sejarah secara interpretatif lebih mudah dipahami tetapi kurang bermanfaat, dibandingkan narasi rinci. Hal ini terjadi karena narasi rinci akan mengemukakan perisitiwa pokok, sehingga pembaca akan lebih mudah menarik generalisasi mereka sendiri, atau membantah generalisasi dari pihak lain (Ricklefs, 2008). Namun begitu, ada pernyataan menarik dari Gottschalk (1985), bahwa sejarawan yang menuliskan kisah tidak menarik, maka dalam hal ini ia merupakan sejarawan yang buruk. Secara profesional ia wajib melukiskan peristiwa dari masa lampau dengan menggairahkan. Ia harus bisa menghidupkan kembali suasananya, di samping melukiskan peristiwanya.

3. Sejarah sebagai ilmu

Sebagai ilmu dan sebagai cerminan dari pengalaman masa lampau, sejarah bersifat selektif. Karena itu, ukuran penting atau tidaknya suatu peristiwa (significance) bisa berubah sesuai dengan perkembangan dan peralihan perhatian. Sebagai ilmu, maka sejarah harus bisa memberikan keterangan (explanation), dan ini berkembang sesuai dengan perkembangan kesadaraan ilmiah (Abdullah, 1978). Oleh sebab itu, terjemahan sejarah sebagai ilmu mengandung arti: sejarah merupakan susunan pengetahuan (body of knowledge) tentang peristiwa dan cerita yang terjadi dalam masyarakat di masa lampau, yang disusun secara sistematis dan metodis berdasarkan asas-asas, prosedur, dan teknik ilmiah yang diakui dan disepakati oleh pakar sejarah. Kaidah-kaidah itu, menurut Miftakhuddin (2021) harus dipenuhi agar informasi yang disajikan sejarah dapat diteima akal sehat dan mengandung nilai manfaat untuk manusia (human being). Sejarah sebagai ilmu mempelajari sejarah sebagai aktualitas dan mengadakan penelitian serta pengkajian tentang peristiwa dan cerita sejarah (Ismaun, 2016).

Lebih lanjut, Ismaun (2016) menggarisbawahi poin pentingnya: sejarah sebagai ilmu merupakan disiplin ilmu tentang masa lalu. Ia merupakan a body knowledge yang diperoleh melalui metode ilmiah, sehingga menjadi fakta/kebenaran. Apa yang membedakan ilmu dan bukan ilmu ialah terletak pada metode ilmiah yang digunakan untuk mendekati dan menemukan kebenaran tersebut.

Sejalan dengan tiga konsep dasar sejarah di atas, menurut Kuntowijoyo (2013), sejarah mempunyai dua karakteristik; negatif dan positif. Negatif meliputi: 1) sejarah bukan mitos, 2) sejarah bukan sastra, dan 3) sejarah bukan ilmu eksak. Sedangkan positif meliputi: 1) sejarah adalah ilmu tentang manusia, 2) sejarah ilmu tentang waktu, 3) sejarah adalah peristiwa yang punya makna sosial, 4) sejarah adalah ilmu tentang sesuatu yang tertentu dan satu-satunya. 


\section{Ruang lingkup sejarah}

Sejarah bercerita tentang manusia, namun manusia yang dituturkan oleh sejarah itu bukan manusia dan masa lalunya secara keseluruhan. Sebab manusia yang sudah menjadi fosil, akan menjadi objek penelitian antropologi ragawi. Demikian pula dengan benda-benda peninggalan, meskipun itu hasil perbuatan manusia juga, tetapi lebih menjadi pekerjaan para arkeolog (Brahmantyo, 2018). Keduanya, baik antropologi maupun arkeologi, merupakan bentuk pembagian secara akademis dari pra-sejarah, yangmana jelas bukan bagian dari sejarah (Santoso, 2014). Sejarah, sebagaimana Kuntowijoyo (1995) di atas, hanya mempunyai kuasa dalam periode waktu sesudah tahun 1500 masehi.

Manakala konsep sejarah telah dapat dipahami secara utuh, barulah ruang lingkup sejarah dapat dipetakan secara komprehensif. Mengacu pada Sjamsuddin (1996), sedikitnya sejarah mempunyai sepuluh ruang lingkup, diantaranya: sejarah sosial, sejarah ekonomi, sejarah kebudayaan, sejarah demografi, sejarah politik, sejarah intelektual, sejarah keluarga, sejarah etnis, sejarah pendidikan, dan sejarah medis. Sebetulnya masih ada satu lagi ruang lingkup sejarah, yakni sejarah rakyat (the history of popular culture), yang merujuk pada sejarah kebudayaan masyarakat yang termarginalkan, tertindas, terkuasai (subordinasi). Namun dalam pembahasan di makalah ini, ruang lingkup tersebut akan dibahas bersama dalam ruang lingkup sejarah kebudayaan (secara umum).

Pertama, sejarah sosial; yang secara ringkas dinyatakan oleh Trevelyan (1942) sebagi sejarah tanpa adanya nuansa politik. Ia juga menegaskan bahwa tanpa adanya sejarah sosial, maka sejarah ekonomi dan sejarah politik tidak akan menemukan mata rantainya untuk menjamah masa lalu kehidupan manusia. Sebab sejarah sosial juga mengkaji manusia dalam hubungan ekonominya serta berbagai kelas masyarakat yang berbeda (Bezucha, 1972). Lebih menukik pada subjek kajian sejarah sosial, Hobsbawm (1971) menjelaskan sejarah sosial sebagai sejarah dari orang-orang miskin atau masyarakat kelas bawah, gerakan-gerakan sosial, dan kehidupan masyarakat secara tradisional.

Mengacu pada rumusan pengertian sejarah sosial sebagaimana dikatakan tiga pakar di atas, maka kita bisa mengambil disertasi Prof. Sartono Kartodirdjo (Pemberontakan Petani Banten 1888, yang kini lebih bisa dibaca publik karena dibukukan) sebagai salah satu contoh pencatatan sejarah sosial di Indonesia. Demikian juga disertasi Prof. Kuntowijoyo (Perubahan Sosial Masyarakat Agraris, Madura 1850-1940, yang juga banyak dikenal publik karena dibukukan). Sejarah sosial di Indonesia, menurut Sjamsuddin (1996), baru mulai populer setelah dipertahankannya disertasi Sartono Kartodirjo pada tahun 1966.

Kedua, sejarah ekonomi; merupakan bidang ilmu yang dipopulerkan oleh Stanley Engerman di Amerika. Secara historis, bidang ilmu ini muncul karena beberapa akademisi kolega Engerman membentuk sebuah komunitas yang menelaah sejarah secara kuantitatif menggunakan data statisitik. Mereka meneliti tentang aspek ekonomi perbudakan Amerika. Fokus dalam karya itu adalah profitabilitas, kelayakan dan efisiensi perbudakan.

Sedangkan dalam konteks Indonesia, sejak 1980 an sejarah ekonomi telah banyak diabaikan, terutama di kampus-kampus (Abdullah \& Surjomihardjo, 1985), dan digantikan dengan ekonomi masa depan yang berorientasi pada pasar bebas. Sejarah ekonomi sekarang ini lebih populer di Amerika, dan negara lain, terutama negara berkembang hanya bisa mengikutinya.

Ketiga, sejarah kebudayaan; yang mengulas secara historis tentang kebudayaan manusia. Penting untuk diketahui, bahwa kebudayaan itu sendiri merupakan semua berwujudan baik struktur maupun proses kegiatan manusia dalam dimensi ideasional, etis, dan estetis. Semua bentuk manifestasi keberadaan manusia baik artifact (fakta benda), mentifact (fakta mentalkejiwaan), dan socifact (fakta sosial), termasuk dalam produk-produk kebudayaan manusia (Kartodirdjo, 1992; Sjamsuddin, 1996). Sedangkan sejarah kebudayaan mengkaji kebudayaan baik berupa proses maupun hasil dari kebudayaan manusia di masa lalu yang mempunyai signifikansi terhadap menusia setelahnya. Inilah yang membedakan sejarah kebudayaan dengan arkeologi, yang mengkaji kebudayaan material, dan antropologi yang mengkaji kebudayaan kultural; sejarah kebudayaan lebih mengkaji kebudayaan dalam aspek temporal. Sejarah kebudayaan sangat berguna dalam penelitian-penelitian sosial yang berusaha mengatasi masalah-masalah sosial temporer dengan cara mempelajari masa lampau dari suatu keompok 
komunitas. Miftakhuddin pernah beberapa kali menggunakan paradigma ini untuk penelitiannya di daerah Jember pada tahun 2018 tentang kecenderungan putus sekolah di Jember, tahun 2019 tentang pemberdayaan masyarakat pinggiran, dan tahun 2021 tentang dilema putus sekolah anak-anak di masyarakat marginal.

Sejauh ini, sejarawan kebudayaan yang cukup terkenal di kalangan akademisi dengan disiplin ilmu sejarah dan kebudayaan adalah Voltaire, Burchardt, dan sejarawan kebudayaan asal Belanda, Johan Huizinga. Salah satu buku karya Huizinga yang terkenal adalah Homo Ludens, yang di dalamnya ia menyebut manusia sebagai mahluk yang suka bermain. Menurutnya, manusia menyepakati mekanisme permainannya dengan seperangkan aturanaturan, kode, atau simbol yang dipahami bersama dan ditaati bersama. Bersandar pada gagasan itu, akademisi Indonesia, Zaini Alif, mengembangkan penelitiannya dengan mengangkat mainan tradisional dari sudut pandang sejarah kebudayaan. Mulai dari skripsi hingga disertasinya mengambil topik permainan tradisional sebagai media transmisi nilai filosofis dalam kehidupan yang diwariskan oleh leluhur.

Sedangkan sejarah kebudayaan rakyat, merupakan semacam bentuk pembalikan dari sejarah kaum elit. Jika kebudayaan elit (atau juga bisa disebut sebagai "kebudayaan tinggi") identik dengan sastra, drama dan musik, maka sejarah kebudayaan rakyat ("kebudayaan rendah") identik dengan pertunjukan dalam bentuk ritual, lagu rakyat, dan festival kerakyatan. Begitu juga jika kebudayaan elit itu eksklusif, maka kebudayaan rakyat ini inklusif (terbuka). Jika kita merujuk pada istilah yang dipakai Gayatri C. Spivak dalam teori postkolonialime, maka rakyat yang dimaksud disini adalah kelompok subaltern, yang merupakan subjek dalam level inferior, bukan superior.

Namun demikian, dikotomi sejarah kebudayaan rakyat dan kebudayaan elit di Indonesia ini belum dikenal (atau lebih tepatnya tidak boleh dikenal) karena ada indikasi jika ini dilakukan maka akan mempertajam kesenjaangan, atau diferensiasi dan stratifikasi sosial. Demikianlah asas normatif-integrarif dalam padangan hidup orang Indonesia. Tetapi yang jelas, Indonesia sebetulnya kaya akan kebudayaan rakyat, seperti upacara ritual petik laut dengan melarungkan sesaji, seni tradisional, sedekah bumi, dan lain sebagainya (Sjamsuddin, 1996).

Keempat, sejarah demografi; yang berfokus pada data perkembangan penduduk di masa lampau. Perkembangan sensus yang sudah ada bahkan sejak abad 16 melahirkan banyak hal tentang kependudukan dan implikasi yang melingkupinya. Ditambah lagi adanya teknik komputasi dan metode statistik dewasa ini, membuat ahli demografi, dengan pertimbangan pengalaman di Barat dapat mengembangkan teori tentang transisi demografi (demographic transition) atau juga biasa disebut dengan siklus demografis (demographic cycle).

Harapannya, teori itu dapat dipakai untuk meramalkan dampak industrialisasi terhadap pergerakan demografi suatu wilayah. Sjamsuddin (1996) mencontohkan masyarakat dengan ekonomi maju, cenderung mempunyai angka kelahiran dan kematian yang menurun, seperti di Prancis abad 18, dan Inggris abad 19. Artinya, perbaikan kesehatan umum tanpa industrialisasi akan menghasilkan pertumbuhan penduduk yang luar biasa.

Kelima, sejarah politik; mempunyai kedudukan yang dominan dalam historiografi Barat, sebagai akibat atas adanya tradisi bahwa sejarah konvensional adalah sejarah politik. Ini dimungkinkan karena sejak sejarah hadir dalam khazanah ilmu pengetahuan (sains) bermula dari pembahasan politik bernuansa aristokrasi (Kartodirdjo, 1992). Sebagai karakteristik sejarah politik, ia selalu mengutamakan pembasahan soal diplomasi dan peran serta tokohtokoh dan pahlawan yang berpengaruh besar terhadap suatu bangsa. Tapi dalam sejarah politik gaya baru, lebih bersifat multidimensional. Sejarah politik lebih menarik karena mempunyai cakrawala eksplanasi lebih luas, seperti: struktur kekuasaan, kepemimpinan, para elit, otoritas, budaya politik, jaringan politik dan sejarah dalam hubungannya dengan sistem dan proses sosial berkelas.

Keenam, sejarah intelektual; yangmana lebih banyak membicarakan soal mentalitas dan ide-ide atau gagasan. Jika diruntut, sejarah intelektual ini berasal dari kebudayaan, yang dimanifestasikan ke dalam artifact (benda), socifact (hubugan sosial), dan mentifact (kejiwaan). Nah, sejarah intelektual menyoal mentifact dalam lintasan sejarah, sebagai fakta kognitif dan kesadaran di alam pikiran atau jiwa manusia. karena itu semua fakta yang nampak sebenarnya 
bersumber pada ekspresi dari apa yang terjadi dalam mental manusia, seperti pikiran, ide, kepercayaan, angan-angan, dan segala macam unsur kesadaran (Kartodirdjo, 1992).

Tidak semua bentuk mentifact meninggalkan bekas seperti halnya artifact, baik berupa dokumen atau pun monumen. Karena itu, telah banyak mentifact yang musnah karena pemikirnya telah tiada. Di sinilah sejarawan harus bisa "merekam" kesadaran itu. Demikianlah alam pikiran manusia masa lalu menjadi pusat perhatian sejarah intelektual. Sebab alam pikiran mempunyai struktur awet dan dapat "direkam". Contoh konkretnya, sejarawan merekan ideologi-ideologi politik liberalisme, sosialisme, konservatisme, gagasan-gagasan John Locke, J.J. Rouseau, Hegel dan sebagainya. Demikian juga revolusi intelektual ilmu-ilmu kealaman (Newton, G. Galilei, C. Darwin) maupun ilmu-ilmu sosial (Adam Smith, Sigmund Freud, Karl Marx).

Ketujuh, sejarah keluarga; diselidiki dengan mengumpulkan informasi mengenai keluarga dari berbagai sumber, mulai dokumen resmi, silsilah keluarga, lukisan lama, naskah perjanjian, dan sebagainya yang tujuannya mencari tahu cikal-bakal keluarga tersebut (Gardner, 1986; Rawson, 1986). Umumnya, orang yang berminat menelaah dalam sejarah keluarga adalah mereka yang ingin mencari pemahaman mengenai cikal bakal keluarganya sendiri. Umumnya para sejarawan keluarga tidak merasa puas hanya mengumpulkan nama dan tanggal-tanggal peristiwanya. Namun mereka juga ingin mempelajari sejarah nenek moyangnya dalam berbagai aspek kehidupan, seperti; masa anak-anak dan remaja, pergaulan dengan teman, tetangga, pekerjaan, pernikahan, kebiasaan-kebiasaan, sampai akhir hayatnya.

Kedelapan, sejarah etnis (etnohistory); mulai banyak digunakan sejak 1940an, yangmana sejarah ini ditulis untuk merekonstruksi sejarah dari kelompok etnis sejak sebelum sampai era kolonialisme Eropa. Contohnya, ialah sejarah suku Maori, sejarah etnis Aztec, sejarah suku aborigin, dan lain-lain. Adapun sumber dalam penulisan sejarah etnis adalah tetap mengutamakan dokumen, dan sejarah lisan maupun tradisi lisan. Sedangkan ruang lingkupnya ialah hampir semua aspek kehidupan etnis turut dikaji dalam sejarah etnis, termasuk aspekaspek sosial, keebudayaan, bahkan kekerabatan.

Kesembilan, sejarah pendidikan; telah begitu nampak di Barat sejak abad 19, dan digunakan untuk membangkitkan kesadaran bangsa, kesatuan budaya, pengembangan profesi keguruan, dan pengembangan lembaga kependidikan. Bidang kajian dalam sejarah pendidikan ini sangat luas; selain menyangkut teori dasar pendidikan dan sistem pendidikan, juga menyangkut pada implikasi adanya lembaga pendidikan terhadap perubahan-perubahan sosial. Meskipun sejarah pendidikan biasanya merunut teori belajar mulai dari behaviorisme hingga multiple intelegences Gardner, namun sejatinya esensi sejarah pendidikan itu sangat luar, mengingat pendidikan juga merupakan proses transmisi kebudayaan yang meliputi teknologi, ide, nilai-nilai spiritual dan estetika (Kartodirdjo, 1992).

Kesepuluh, sejarah medis; yangmana penulisannya dilatarbelakangi oleh kebutuhan para dokter yang menyadari pentingnya memahami tentang tradisi pengobatan masa lalu. Sumpah kedokteran yang digagas oleh Hippocrates sejak sekitar 400 tahun sebelum masehi adalah salah satu literatur dan bukti kebutuhan para dokter masa kini akan prosedur dan metode pengobatan untuk para pasien. Tahun 195a an, sejarah medis sebagai bagian dari ilmu kedokteran mulain diperkenalkan di kampus-kampus Eropa dan Amerika. Prinsipnya sederhana, ialah karena memungkinkan untuk terungkapnya berbagai kesalahan, dan menempatkan ilu pengetahuan di atas keyakinan takhayul (Bynum, 2000).

\section{Nilai-nilai moral dalam sejarah}

Pengalaman masa lalu seseorang, membentuk kepribadian sekaligus identitasnya. Hal ini juga berlaku secara kolektif, yakni pengalaman atau sejarahnya -lah yang membentuk kepribadian nasional serta identitas nasionalnya. Cita-cita dan nilai kebangsaan tidak bisa diketahui tanpa merujuk referensi pengalaman sejarah tersebut (Soedjatmoko, 1973).

Bangsa yang tidak mengenal sejarahnya, ibarat orang yang kehilangan memorinya, ialah orang pikun atau sakit jiwa. Otomatis hilang pula kepribadian dan identitasnya (Kartodirdjo, 1992). Sebagaimana Collingwood (1956); ...knowing your self means knowing that you can do; ...the only clue to what man can do is what man has done. The value is, then,history theachs us what 
man has done, and then what man is.... Oleh sebab itu, sejarah dalam konteks ilmu sosial, mempunyai nilai moral berupa pembentukan indentitas secara individu maupun secara kolektif, dengan syarat bahwa individu atau masyarakat tersebut mempunyai kesadaran sejarah.

Kesadaran sejarah membuat manusia berusaha menghargai kerja keras dan kerumitan atas upaya mengungkap persitiwa penting yang memunculkan perubahan sosial masa lalu, dan berdampak pada masa sekarang. Kesadaran sejarah juga akan membuat manusia menghargai keunikan masing-masing keadaan, dan bahkan dalam kecenderungan tertentu. Melalui kesadaran sajarah, menurut Soedjatmoko (1973), orang dapat melihat realitas sosial yang dihadapi dengan segala problemnya. Bukan saja sebagai masalah moril yang memerlukan jawaban iya atau tidak, hitam atau putih, melainkan agar dapat melihat masalah sosial termasuk segi morilnya, sebagai masalah historis yang juga memerlukan cara penghadapan historis pula.

Kesadaran sejarah membantu manusia waspada terhadap pemikiran yang terlalu sederhana, analogi yang terlalu dangkal, analisis yang terlalu tumpul, serta penerimaanpenerimaan yang terlalu mudah membelokkan (determinisme sejarah). Artinya, kesadaran sejarah mampu mengelakkan kita dari kecenderungan-kecenderungan fenomena yang buta. Karena luasnya tentang kesadaran sejarah, Soedjatmoko (1976) menyebutnya sebagai orientasi intelektual yang bersifat kreatif, mawas diri, dan introspeksi yang tiada hent; self understanding.

Sedangkan bagi Kartodirdjo (1990), kesadaran sejarah secara imanen ada pada refleksi diri, dan berguna untuk: 1) menempatkan posisi diri dalam konteks sosiokultural serta konteks temporal; 2) melepaskan diri dari perhatian kognitif serta kehidupan praktis yang menuntut terselenggaranya fungsi-fungsi atau kepentingan perhatian normatif-etis dalam menghayati sejarah dengan orientasi teleologis, seperti kepentingan politikkebudayaan; 3) membantu mencari jawaban dari permasalahan metahistoris melalui penggambaran masa depan atau fungsi prediktif dari studi sejarah. Perlu dipahami kata kunci dalam poin ketiga ialah prediktif, sebab menurut Collingwood, urusan sejarawan adalah mengetahui masa lalu, bukan mengetahi masa depan. Jika sejarawan dapat memastikan masa depan, berarti ada yang salah dengan konsep pemahamannya soal sejarah (Christian, 2004).

Jika manusia menyadari kemungkinan untuk ikut andil "membentuk" masa depannya, berarti ia menerima tanggung-jawab tersebut sebagai bagian dari penegasan kebebasannya. Dengan demikian sejarah tidak lagi diterima sekedar sebagai pemuas rasa ingin tahu manusia belaka, atau sumber kekaguman narsistiknya, melainkan menjadi sesuatu yang amat penting bagi orientasi partisipasi yang bermakna untuk kehidupan manusia. Di sinilah pentingnya sejarah mempunyai dorongan emansipatoris, yang merupakan dorongan pencarian dan penegakan kebebasan diri dan masyarakat memperbesar kemungkinan keberhasilan dalam "mengubah" maupun "mengendalikan" nasibnya. Dalam hal ini seorang sejarawan harus menunjukkan kebebasannya untuk menentukan sikapnya yang bertanggungjawab.

\section{Tujuan dan manfaat memplajari sejarah}

Barzun menyatakan bahwa sejarah menggembleng jiwa manusia menjadi kuat dan tahan dalam menghadapi teror dan kekacauan dalam kehidupan kita. Lain lagi pendapat dari Cicero yang menyatakan bahwa barang siapa tidak mengenal sejarahnya akan tetap menjadi anak kecil. Sementara itu, Seignobos mengatakan sejarah mempunyai pengaruh higienis terhadap jiwa kita karena membebaskan dari sifat-sifat serba percaya belaka (Santoso, 2014). Tetapi, terlepas dari alasan idealis itu, tetap ada alasan praktis yang membuktikan bahwa sejarah mempunyai use value (nilai kegunaan) bagi kehidupan manusia. Seorang bijak pernah berkata: semua orang punya dua cara untuk menjadi baik. satu, berasal dari pengalamannya sendiri, dan satunya adalah belajar dari pengalaman orang lain. kurang lebih, itulah poin pokok yang mendasari alasan mengapa seseorang penting untuk belajar sejarah.

Sementara itu, menurut Kartodirdjo (1992) sejarah mempunyai kegunan didaktis dan genetis. Tapi beberapa sejarawan masa kini menambahkan adanya kegunaan pragmatis. Didaktis artinya sejarah dapat mendidik/memberikan pelajaran, hikmah ataupun ilham bagi pembacanya di masa sekarang, dan menjadi peringatan untuk masa depan. Genetis artinya sejarah dapat mengungkapkan sebab musabab suatu peristiwa. Sedangkan pragmatis artinya melegitimasi kekuasaan penguasa terdahulu agar nampak hebat dikenal orang-orang masa kini. 
Menurut Notosusanto (1979), ada fungsi lain orang mempelajari sejarah, diantaranya fungsi intsruktif dan rekreatif. Fungsi instruktif maksudnya sejarah dapat mengajarkan kejuruan/keterampilan tertentu, seperti: navigasi, jurnalistik, militer dan sebagainya. Fungsi rekreatif maksudnya dapat memberi kesenangan. Pebelajar sejarah dapat terpesona kisah sejarah yang mengagumkan, yang digambarkan melalui pelbagai evidensi dan imajinasi. Mempelajari berbagai peristiwa menarik di berbagai tempat (negara maupun bangsa), ibarat berwisata di tempat itu menggunakan lorong waktu. Jika fakta itu kemudian direfleksikan dengan pengajaran di tingkat satuan pendidikan, bisa kita ambil bahwa pengetahuan sejarah disampaikan adalah sejarah sebagai tafsiran (history as interpretation), dan wujud cerita sejarah. Cerita sejarah menghubungkan kita dengan generasi masa lampau dan merenungkan kembali peristiwa yang mereka hadapi dan kebudayaan yang mereka jalani. Sebab peristiwa dan kebudayaan manusia adalah subjek sejarah, yang pada gilirannya menyediakan jangkauan yang sangat luas untuk mendidik generasi muda. Di sekolah-sekolah, sejarah biasanya dikemas dan disajikan ke dalam sastra anak dengan genre realisme. Tujuannya adalah untuk memvisualisasikan fokus-fokus penting dalam pengalaman tokoh agar lebih mudah diserap tauladannya bagi siswa sekolah (Miftakhuddin, 2020). Inilah peran penting pendidikan sejarah dalam ilmu humaniora (Dasuki, 2003). Namun demikian, karena guru (bisa jadi) tidak menyaksikan sendiri kejadian-kejadian yang diterangkannya, ia harus dapat menunjukkan sumber-sumber dimana keterangan-keterangannya itu diperoleh. Hal ini perlu sebagai pegangan apakah peristiwa yang dijelaskannya itu dapat dipertanggung jawabkan atau tidak (Ismaun, 2016).

Rekaman yang diperoleh ilmu sejarah mempunyai peran sebagai bendahara memori peristiwa masa lampau masyarakat luas. Kurang lebih begitulah ungkapan filsuf ternama dari Inggris, Bertrand Russell (1955). Dengan kata lain, sejarah sebagai media penyimpan memori kolektif dapat menjadi dasar pengakuan identitas kolektif suatu masyarakat. Demikian juga kata Collingwood (1956), bahwa belajar sejarah itu untuk self-knowledge (tahu diri), sehingga puncak pencapaian studi sejarah adalah kesadaran sejarah

\section{Simpulan dan saran}

Sejarah merupakan bagian dari ilmu sosial yang sebetulnya bisa dipahami dengan mudah jika mengikuti bagaimana cara berpikir sejarawan dan bagaimana cara kerja metodologi sejarah. Tidak seperti profesi dokter yang harus diisi oleh orang dari disiplin ilmu kedokteran. Siapapun bisa menjadi sejarawan, karena sejarah merupakan ilmu yang terbuka. Setiap orang punya kesempatan yang sama untuk menjadi sejarawan selaman dia bisa menjalankan metodologi sejarah dengan konsisten dan baik. Demikian juga dengan pemahaman sejarah.

Sejarah harus dipahami dari berbagai sudut pandang sebagaimana berbagai ruang lingkup yang dimiliki oleh sejarah. Bagi orang-orang keguruan atau kependidikan, pemahaman tentang kedudukan sejarah dalam ilmu sosial dan kedudukan sejarah dalam IPS, akan sangat membantu dalam menyampaikan materi sejarah di ruang-ruang kelas. Terlebih lagi jika mereka dapat mengamalkan kaidah penyampaian sejarah sesuai dengan jenjang pendidikan siswa di satuan pendidikan.

Sebagai referensi, Kuntowijoyo (2013) pernah menyinggung bagaimana sejarah seharusnya diajarkan di ruag-ruang kelas. Menurutnya, sejarah untuk SD harus disampaikan dengan pendekatan estetis, yang tujuannya semata-mata untuk menanamkan rasa cinta kepada bangsa dan tanah air melalui kisah perjuangan pahlawan. Sejarah untuk jenjang SMP disampaikan dengan pendekatan etis, yang tujuannya untuk membuat siswa mengerti bahwa mereka hidup bersama orang dari kebudayaan lain baik dulu maupun sekarang. Sedangkan untuk jenjang SMA, diajarkan dengan pendekatan kritis, yang tujuannya untuk memberitahu apa yang sebenarnya terjadi dan kemana arah kejadian-kejadian itu. Adapun dalam jenjang pendidikan tinggi, sejarah perlu diajarkan secara akdemis, yang biasanya berbicara tentang perubahan masyarakat, agar mahasiswa tahu latar belakang suatu masyarakat, mempunyai gambaran tentang kesinambungan dan perkembangan, dan dapat mengantisipasi perubahan yang akan terjadi dengan mengamalkan ilmunya. 


\section{References}

Abdullah, T. (1978). Sejarah lokal di Indonesia. Yogyakarta: Gadjah Mada University Press.

Abdullah, T., \& Surjomihardjo, A. (1985). Ilmu sejarah dan historiografi, arah dan perspektif. Jakarta: Gramedia.

Arnold, J. H. (2000). History: A Very Short Introduction. Oxford: Oxford University Press. https://doi.org/10.1093/actrade/9780192853523.001.0001

Bezucha, R. J. (1972). Modern European social history. Lexington: D. C. and Company.

Brahmantyo, K. (2018). Pengantar ilmu sejarah. Jakarta: Direktorat Sejarah, Kemdikbud.

Bynum, W. F. (2000). Sejarah medis. In Ensiklopedi ilmu-ilmu sosial. Jakarta: Raja Grafindo Persada.

Christian, D. (2004). Maps of time, an introduction to big history. Berkeley: University of California.

Collingwood, R. G. (1956). The idea of history. London: Oxford University Press.

Dasuki, A. (2003). Historiografi dan penggunaan sejarah dalam pendidikan. In Historia Magistra Vitae: Menyambut 70 Tahun Prof. Dr. Hj. Rochiati Wiriaatmadja, MA. Bandung: Historia Press.

Gardner, J. F. (1986). Women in Roman law and society. London: Allen \& Unwin.

Gottschalk, L. (1985). Mengerti Sejarah (Terj. Nugroho Notosusanto). Jakarta: UI Press.

Hobsbawm, E. J. (1971). From social history to the history of society. The MIT Press on Behalf of American Academy of Arts \& Sciences, 89(1), 3-12.

Ismaun. (2016). Pengertian dan konsep sejarah. In Ilmu Sejarah dalam PIPS. Tangerang: Universitas Terbuka.

Kartodirdjo, S. (1990). Fungsi sejarah dalam pembangunan bangsa, kesadaran sejarah, identitas, dan kepribadian nasional. Yogyakarta: Universitas Gadjah Mada.

Kartodirdjo, S. (1992). Pendekatan ilmu sosial dalam metodologi sejarah. Jakarta: Gramedia Pustaka Utama.

Khoiron, M., \& Wahyuningtyas, N. (2020, February). Revitalization of Social Studies Education: A Developmental Study Based on Dick and Carey Instructional Design. In International Conference on Social Studies and Environmental Issues (ICOSSEI 2019) (pp. 37-42). Atlantis Press.

Murwonugroho, W., \& Miftakhudin, M. (2020). Kajian Rupabheda: Tokoh-Tokoh Sri Tanjung pada Relief Candi Penataran. Panggung, 30(2).

Kuntowijoyo. (1995). Pengantar ilmu sejarah. Yogyakarta: Yayasan Bentang Budaya.

Kuntowijoyo. (2013). Pengantar ilmu sejarah. Yogyakarta: Tiara Wacana.

Miftakhuddin, M. (2018). Kecenderungan Putus Sekolah Difabel Usia Pendidikan Dasar di Jember. INKLUSI Journal of Disability Studies, 5(1), 95-114.

Miftakhuddin, M. (2019). Dedication of Unej Mengajar to Improve the Human Resources' Quality in the Retarded Areas of Jember through a Participatory Approach. Proceeding of Community Development, 2, 454-466.

Miftakhuddin, A. M., \& Zulfiati, H. M. (2019). Misconceptions between Social Studies and Social Sciences among Pre-Service Elementary Teachers. International Journal of Education, $12(1), 16-25$.

Miftakhuddin, M. (2020). Historiografi Korupsi di Indonesia: Resensi Buku Korupsi dalam Silang Sejarah Indonesia. Rihlah: Jurnal Sejarah dan Kebudayaan, 7(2), 168-172.

Miftakhuddin, M. (2020). Kolonialisme: Eksploitasi dan pembangunan menuju hegemoni.

Miftakhuddin, M. (2021). Pendekatan penelitian pendidikan: Tinjauan dari perspektif filsafat ilmu.

Miftakhuddin, M. (2020). Sastra anak: Genre realisme.

Miftakhuddin, M. (2021). Dilema putus sekolah bagi anak-anak masyarakat tradisional di Jember, Jawa Timur.

Notosusanto, N. (1979). Sejarah demi masa kini. Jakarta: Universitas Indonesia Press.

Rawson, B. (1986). The family in ancient Rome. London: Allen \& Unwin.

Ricklefs, M. C. (2008). Sejarah Indonesia Modern, 1200 - 2004. Jakarta: Serambi.

Russell, B. (1955). Unpopular Essays. London: Allen \& Unwin. 
Santoso, A. (2014). Arsip sejarah lisan. Tangerang: Universitas Terbuka.

Senen, A. (2014). Mengembangkan pembelajaran IPS dalam perspektif paradigma konstruktivistik. Jurnal Pendidikan Dasar Dinamika, 6(2), 180-196.

Sjamsuddin, H. (1996). Metodologi sejarah. Jakarta: Depdikbud.

Soedjatmoko. (1973). Kesadaran sejarah dan pembangunan. Jakarta: Fakultas Sastra Universitas Indonesia.

Soedjatmoko. (1976). Kesadaran sejarah dalam pembangunan. Prisma, (7).

Sunal, C. S., \& Haas, M. E. (2011). Social studies for the elementary and middle grades, a constructivist approach (4th ed.). London: Pearson Education.

Trevelyan, G. M. (1942). English social history, a survey of six centuries. London: Allen \& Unwin. 